\title{
Göçer Ailelerin Hayvancılıkta Sürü Yönetimi ve Yaylacılık Faaliyetleri: Türkiye, Iğdır İli Örneği ${ }^{*}$
}

\author{
İsa YILMAZ ${ }^{\text {*** }}$, İsak SAVAŞ ${ }^{2}$, Mete YANAR ${ }^{3}$ \\ ${ }^{1}$ Muş Alparslan Üniversitesi, Uygulamalı Bilimler Fakültesi, Hayvansal Üretim ve Teknolojileri Bölümü, Muş, TÜRKIYYE \\ ${ }^{2}$ Iğdır Üniversitesi, Ziraat Fakültesi, Zootekni Bölümü, Iğdır, TÜRKIYE \\ ${ }^{3}$ Atatürk Üniversitesi, Ziraat Fakültesi, Zootekni Bölümü, Erzurum, TÜRKIYE
}

\begin{tabular}{|c|c|}
\hline Geliş Tarihi/Received: 08.11 .2019 & Kabul Tarihi/Accepted: 16.02 .2020 \\
\hline \multicolumn{2}{|l|}{ ORCID ID (Yazar surasma göre / by author order) } \\
\hline \multicolumn{2}{|c|}{ (1Dorcid.org/0000-0001-6796-577X (1D) orcid.org/0000-0002-8310-3317 (1D) orcid.org/0000-0002-5311-5675 } \\
\hline
\end{tabular}

Öz: Bu çalıșma, göçer ailelerin sürü yönetimi ve yaylacılık faaliyetlerini belirlemek amacı ile 2017-2018 yılları arasında Türkiye'nin Doğu Anadolu Bölgesi'nde yer alan Iğdır ilinde yürütülmüştür. Damızlık Koyun-Keçi Yetiştiricileri Birliği'ne kayıtlı 174 yetiştirici ile anket yapılmıştır. İstatistiki değerlendirmede $\chi^{2}$ (Ki-Kare) testi kullanılmıştır. Araştırmada; Yetiştiricilerin \% 25.2'sinin okur-yazar olmadığı ve \% 74.8'inin bir eğitim seviyesine sahip oldukları belirlenmiştir. İşletmelerde \% 8.6 oranında sağım yapılmaz iken \% 91.4'ünde yapıldığı anlaşılmıştır. Koyunlarda kuzu emzirme ve sağım süresi sırasıyla $147.18 \pm 1.55$ ve $59.02 \pm 2.00$ gün olarak belirlenmiştir. Koyunlarda günlük süt verimi ortalama $238.36 \pm 10.02$ g gün ${ }^{-1}$ olarak belirlenmiştir. Koyunlara yem verme öğün sayısının $2.91 \pm 0.03$ kez olduğu, anaç koyun başına ortalama verilen kesif yem, misır silajı, saman ve kuru ot miktarları sırasıyla 566.38 $\pm 15.68,700.00 \pm 118.02(\mathrm{n}=8), 900.00 \pm 55.09$ ve $1449.70 \pm 43.89 \mathrm{~g}$ olarak belirlenmiştir. Yetiştiricilerin \% 80.5'i sütü satmakta, \% 10.9’u öz tüketimde kullanmakta ve \% 8.6'sı ise sağım yapmamaktadır. Sonuç olarak, Iğdır ilinde yarı göçer ailelerin küçükbaş hayvan yetiştiriciliği konusunda geleneksel yetiştiricilik yaptıkları ve tecrübeli oldukları kanaatine varılmıştır.

Anahtar Kelimeler: Otlatma, çiftlik yapısı, geleneksel yetiştiricilik, küçükbaş hayvancılık, yarı göçer

\section{Herd Management and Transhumance Activities of Nomadic Families in Animal Breeding: Case of Iğdır Province, Turkey}

Abstract: This research was carried to determine the herd management and transhumance activities of the nomads between 2017-2018 years at in Iğdır province in South Anatolia Region of Turkey. A survey was conducted with 174 breeders registered in the Sheep-Goat Breeders Association. $\chi^{2}$ (Chi-Square) test was used for statistical analyses. It is determined that $25.2 \%$ of the breeders are illiterate while $74.8 \%$ hold a diploma of some level. Milking is carried out in $91.4 \%$ of the farms while no milking is done in the remaining $8.6 \%$. Suckling time of lamb and milking time in the sheep was $147.18 \pm 1.55$ and $59.02 \pm 2.00$ days, respectively. Total milk yield of sheep is determined $238.36 \pm 10.02 \mathrm{~g} \mathrm{day}^{-1}$. The number of feeding times of the sheep was determined as $2.91 \pm 0.03$. The average amount of concentrate forage, corn silage, straw, and dry weed were determined as $566.38 \pm 15.68,700.00 \pm 118.02(\mathrm{n}=8), 900.00 \pm 55.09$ and $1449.70 \pm 43.89 \mathrm{~g}$, respectively. $80.5 \%$ of the growers sell milk, $10.9 \%$ use it in self-consumption and $8.6 \%$ do not milk. As a result, it is concluded that the semi-nomadic families in Iğdır province practice traditional breeding and are experienced in ovine breeding.

Keywords: Grazing, farm structure, traditional breeding, sheep and goat farming, semi-nomadic

": Bu çalı̧̧ma, Iğdır Üniversitesi Fen Bilimleri Enstitüsü tarafından kabul edilen ikinci yazara ait "Iğdır İlinde Göçer Hayvancılık" isimli Yüksek Lisans Tez çalışmasının bir bölümünden üretilmiştir. 


\section{Giriș}

Hayvancılık işletmelerinin ulusal ve uluslararası piyasalarda rekabet ederek sürdürülebilirliklerini sağlamaları için maliyetlerin yaklaşık \% 60'ını oluşturan yem giderlerini azaltmaları gereklidir (Yolcu ve Tan, 2008). Kaba yem açı̆̆ının kapatılmasında daha çok kesif yemlere yer verilmesi ise maliyetleri arttırmaktadır (Kuşvuran ve ark., 2011). Hayvancilıkta maliyetlerin azaltılması ve karlılı̆̆ sağlamak için hayvanları sıcaklık stresinden korumak, verim kaybını azaltmak ve ucuz kaliteli kaba yem temin etmek amacıyla yüksek kesimlerdeki mera ve yaylalara çıkarmak gereklidir (Daşcı ve Çomaklı, 2006).

Genellikle tüm dünyada yaygın ve uzun geleneğe sahip olan yüksek kesimlere çıkarak yapılan hayvancılık şekli göçerliktir (Herzog ve Seidl, 2018). Göçerlik; (a) sürekli (konar-göçer), (b) yarı göçerlik ve (c) yaylacılık faaliyeti olmak üzere 3 şekilde yapılmaktadır (Aygün ve Sezgin, 2009; Küçükilhan ve ark., 2011; Kaymakç1, 2016).

Sürekli göçerlik şeklinde; yetiştiriciler ve hayvanlar için sürekli bir yerleşim ve barınak söz konusu olmayıp, mevsimsel değişimi izleyerek yıl boyunca devam eden bir otlatma döngüsü söz konusudur (Kaymakçı, 2016). Yarı göçerlik şekli; yerleşik düzende (köylerde), ekonomilerinin temelini göçer hayvancılığın oluşturduğu, göçebelikle-yerleşik arasında bir ara tip olarak beliren ve köy-yayla hayatı yarı göçer nitelikleri ağır basan biçimlerde sürdüren toplulukların yaşama biçimidir (Küçükilhan ve ark., 2011). Yaylacılık faaliyeti ise yetiştiricilerin hayvan sürülerini otlatmak amacıyla özellikle sıcak yaz aylarında, hayvanlarıyla birlikte yüksek rakımlı yerlere göç etmek suretiyle gerçekleştirdikleri tarımsal bir faaliyettir (Daşcı ve Çomaklı, 2006; Yaz1c1, 2016).

Göçerlik, geleneksel yaşam tarzı ve hayvancılıkta geçim faaliyeti olarak korunması gereken bir kültürdür (Uzun ve Köse, 2012). Ülke ekonomisine sağlanacak katkıları ile birlikte doğal kaynakların ekonomik şekilde değerlendirilmesi, hayvansal üretimde kullanılması, küçükbaş hayvan yetiştiriciliğinin sürdürülebilirliğinin sağlanması; göçerlikle hayvancılık yapan ailelerin desteklenmesi, bu hayvancılık şeklinin korunması ve mevcut sorunlarına çözüm getirilmesi ile mümkündür (Aygün ve Sezgin, 2009).

Göçerlikte karşılaşılan sorunlar; araçlarla hayvan taşımada yaşanan güçlükler, resmi makamlarca göçer ailelerin yaya olarak hayvanlarını götürmelerine izin verilmemesi, yayla kiralamada yaşanan problemler, çoban bulamama, bazı yaylalara zaman zaman yasak konması, merada su ihtiyacının karşılanamaması, mera ve yayla yollarının olmaması veya doğal nedenlerle sıklıkla bozulması, üretilen ürünlerin değerinde pazarlanamaması, aile bireylerinin yeterince eğitim ve sağlık hizmeti alamamaları şeklinde sıralanabilmektedir (Savaş ve ark., 2019).

$\mathrm{Bu}$ çalışmada; hayvancılık faaliyetinin yoğun olduğu Iğdır ilinde, yarı göçer ailelerin hayvancılıkla ilgili sürü yönetimini ve bazı yaylacılı faaliyetlerini belirlemek ve olası sorunlara çözüm önerileri geliştirmek amaçlanmıştır.

\section{Materyal ve Yöntem}

\subsection{Materyal}

Bu çalışmanın materyali; Iğdır ilinde yarı göçer hayvancılıkla hayvancılık faaliyetini sürdüren, 2016 yılında faaliyet gösteren, Damızlık KoyunKeçi Yetiştiricileri Birliği'ne kayıtlı ve devlet teşviklerinden faydalanan 2 bin 363 işletme sahibi içerisinden örnekleme yöntemiyle seçilen 174 kişi ile yapılan anket çalışmasından oluşmaktadır.

\section{2. Örnekleme sayısının belirlenmesi}

Anket yapılacak işletme sahiplerinin belirlenmesinde, materyal k1sminda belirtilen bilgiler dikkate alınarak Yamane (2010) tarafından bildirilen Eşitlik 1 kullanılmıştır.

$$
n=\frac{N s^{2}}{(N-1) x D^{2}+s^{2}}
$$

Eşitlikte yer alan $n$, popülasyonu temsil eden işletme sayısını (adet); $N$, popülasyondaki toplam işletme sayısını (2.363 adet); $S$, popülasyonun standart sapmasinı (107.168); $D$, düzeltme faktörünü ifade etmektedir. Düzeltme faktörü (D)= $(\mathrm{E} / \mathrm{t})^{2}$ formülü ile hesaplanmaktadır. Bu formülde $\mathrm{t}$ katsayısı \% 90 güven sınırları için 1.6445 olarak alınmış, E ise hata terimi olup (12.9), ilgili büyüklük grubu ortalamasının \% 10'u dur.

$$
\begin{aligned}
& \mathrm{N}=2363, \overline{\mathbf{x}}=129.132, \mathrm{~S}=107.168 \\
& n=\frac{2363 x(107.168)^{2}}{(2363-1) x(12.9 / 1.6445)^{2}+(3047)^{2}}=174
\end{aligned}
$$

Popülasyonu temsil eden işletme sayısı 174 olarak bulunmuştur.

\section{3. İstatistiksel değerlendirme}

Anket yoluyla elde edilen veriler, excel programı yardımıyla düzenlenerek analize hazır hale getirilmiştir. Sayılarak iki boyutlu tablolar şeklinde özetlenebilen özelliklerde, bulgular sayı ve yüzdelik şeklinde ifade edilmiş ve analitik değerlendirmelerde $\chi^{2} \quad($ Ki-Kare $)$ testi 
kullanılmıştır (Yıldız ve ark., 2006). Excel formatında hazırlanan veriler SPSS 22.0 paket programinda istatistiksel olarak değerlendirilmiştir.

\section{Bulgular ve Tartışma}

Başarılı bir hayvancılık için yetiştiricilerin eğitim seviyeleri önemlidir. Konu ile ilgili olarak Iğdır ilinde yarı göçer hayvancılıkla geçimini sağlayan kişilerin eğitim durumları sorgulanmış ve alınan bilgiler Tablo 1'de özetlenmiştir. Yarı göçer ailelerin eğitim seviyeleri incelendiğinde, yetiştiricilerin \% 25.2'sinin okur-yazar olmadığı ve çoğunlukla ilkokul seviyesinde (\% 51.1) eğitime sahip oldukları belirlenmiştir. Genel olarak değerlendirildiğinde ise yetiştiricilerin \% 74.8'i bir eğitim seviyesine sahiptir (Tablo 1). Yarı göçer ailelerin herhangi bir eğitim seviyesine sahip olmaları ile ilgili elde edilen değer; Burdur ilinde Bilginturan ve Ayhan (2009)'1n (\% 98.5) ve Niğde ilinde Ceyhan ve ark. (2015)'nın (\% 95.8) elde ettikleri değerlerden düşük iken, Şanlıurfa ve Hakkâri ilinde koyunculuk işletmelerinde Karadaş (2017, 2018)'ın (sirasiyla, \% 58.3 ve \% 62) bildirdiği bulgulardan yüksek olduğu görülmüştür.

Karlı bir hayvancılık için yem giderlerinin az maliyetli olması istenir. $\mathrm{Bu}$ amaçla yetiştiricilerin arazi varlıkları incelenmiş ve Tablo 2'de özetlenmiştir. Toplam arazi varlığı bakımından işletmeler arasında farklılık gözlemlenmemiş olmasına rağmen, silajlık mısır ekimi bakımından işletmeler arasındaki farklılık önemli bulunmuştur $(\mathrm{p}<0.001)$. İşletmelerin ortalama arazi varlığ $155.32 \pm 55.19$ dekar olarak tespit edilmiştir (Tablo 2). Çalışmada elde edilen ortalama arazi varlığına ait değer; farklı koyunculuk işletmelerinde Karadaş (2017, 2018) (sırasiyla 39.6 da ve 14.0 da), Bilginturan ve Ayhan (2009) (39.17 da) ve Tamer ve Sarı̈zkan (2017) (130.5 da) tarafindan tespit edilen değerlerden yüksek olduğu görülmüştür.

Tablo 1. Göçer yetiştiricilerin ilçelere göre eğitim seviyeleri

\begin{tabular}{|c|c|c|c|c|c|c|c|}
\hline \multirow{2}{*}{ İlçeler } & & \multicolumn{5}{|c|}{ Eğitim durumu } & \multirow[b]{2}{*}{ Toplam } \\
\hline & & Yok & İlkokul & Ortaokul & Lise & Ön lisans+ & \\
\hline \multirow{2}{*}{ Merkez } & $\mathrm{n}$ & 22 & 45 & 6 & 8 & 5 & 86 \\
\hline & $\%$ & 25.6 & 52.3 & 7.0 & 9.3 & 5.8 & 100.0 \\
\hline \multirow{2}{*}{ Karakoyunlu } & $\mathrm{n}$ & 7 & 15 & 7 & 4 & 1 & 34 \\
\hline & $\%$ & 20.6 & 44.1 & 20.6 & 11.8 & 2.9 & 100.0 \\
\hline \multirow{2}{*}{ Aralık } & $\mathrm{n}$ & 11 & 22 & 3 & 4 & 1 & 41 \\
\hline & $\%$ & 26.8 & 53.7 & 7.3 & 9.8 & 2.4 & 100.0 \\
\hline \multirow{2}{*}{ Tuzluca } & $\mathrm{n}$ & 4 & 7 & 2 & 0 & 0 & 13 \\
\hline & $\%$ & 30.8 & 53.8 & 15.4 & 0.0 & 0.0 & 100.0 \\
\hline \multirow{2}{*}{ Genel } & $\mathrm{n}$ & 44 & 89 & 18 & 16 & 7 & 174 \\
\hline & $\%$ & 25.2 & 51.1 & 10.3 & 9.2 & 4.0 & 100.0 \\
\hline
\end{tabular}

Tablo 2. İşletmeler bazında arazi varlığı ve ekim miktarları

\begin{tabular}{lccccccc}
\hline Arazi varlikları (da) & $\mathrm{N}$ & $\overline{\mathbf{X}}$ & $\mathbf{S}_{\overline{\mathbf{x}}}$ & Minimum & Maksimum & $\mathrm{F}$ \\
\hline Toplam arazi & 174 & 155.32 & 55.19 & 0 & 6450 & 0.470 & $\mathrm{p}>0.05^{\text {ös }}$ \\
Kuru arazi & 174 & 14.05 & 2.78 & 0 & 280 & 1.883 & $\mathrm{p}<0.01^{* *}$ \\
Sulu arazi & 174 & 39.58 & 4.84 & 0 & 450 & 0.716 & $\mathrm{p}>0.05^{\text {ös }}$ \\
Yem bitkisi & 174 & 29.30 & 3.28 & 0 & 298 & 0.608 & $\mathrm{p}>0.05^{\text {ös }}$ \\
Silajlik misir & 174 & 1.84 & 0.72 & 0 & 100 & 7.817 & $\mathrm{p}<0.001^{* * *}$ \\
Çayir-mera & 174 & 9.74 & 2.45 & 0 & 350 & 0.882 & $\mathrm{p}>0.05^{\text {ös }}$ \\
Yayla & 174 & 91.95 & 22.99 & 0 & 6000 & 0.105 & $\mathrm{p}>0.05^{\text {ös }}$ \\
Hububat & 174 & 12.52 & 1.89 & 0 & 130 & 0.939 & $\mathrm{p}>0.05^{\text {ös }}$ \\
\hline
\end{tabular}

ös: önemsiz, ${ }^{* *}: \mathrm{p}<0.01$ seviyesinde önemli, $* * *$ : $\mathrm{p}<0.001$ seviyesinde önemli

İşletmelerdeki sağım ve sağımcı durumu; sağım yapılmaması, ev halkından kadın, ev halkından kadın + dışarıdan işçi şeklinde değerlendirilmiştir. Elde edilen bilgiler Tablo 3'te özetlenmiştir. Yarı göçer ailelerin \% 91.4'ünün hayvanlarını sağdıkları ve \% 8.6'sının ise sağmadıkları belirlenmiştir. Sağım yapılan tüm işletmelerde sağımın elle yapıldığ 1 ve sağımı $\% 86.8$ oranında ev halkından kadınların, \% 4.6 oranında ise ev halkından kadınların yanında işçiler tarafından yapıldığı tespit edilmiştir (Tablo 3). Bu çalışmada yarı göçerlikle yetiştiricilik yapan ailelerin işletmelerinde hayvanlarını sağma ve sağmama durumları ile ilgili elde edilen değerler; Yozgat ilindeki koyunculuk işletmelerinde sırasıyla \% 60.3 ve \% 39.7 olarak tespit edilmiştir (Tamer ve Sarı̈zkan, 2017). Literatürdeki bu değerler çalışmada elde edilen sağım yapılma 
durumu değerinden düşük, sağım yapılmama durumu için elde edilen değerden yüksektir. Niğde ili koyunculuk işletmelerinde sağım yapılma ve yapılmama durumu sirasiyla \% 22.2 ve \% 77.9 olarak elde edilmiştir (Ceyhan ve ark., 2015). Ceyhan ve ark. (2015)'nın bu verileri ile çalışmamız sonuçları arasında tersi bir bulgu söz konusu olup, sağım yapılmayan işletme sayısı daha fazladır. Koyunculuk işletmelerindeki bu farklılıkların yetiştiricilerin sürü yönetimi ile ilgili uygulamalarından ileri geldiği söylenebilir.

Tablo 3. İşletmeler bazında sağım ve sağımcı bilgileri

\begin{tabular}{|c|c|c|c|c|c|}
\hline \multirow{2}{*}{ İlçeler } & & \multirow[b]{2}{*}{$\begin{array}{c}\text { Sağım } \\
\text { yok }\end{array}$} & \multicolumn{2}{|c|}{ Sağımcı kişi } & \multirow[b]{2}{*}{ Toplam } \\
\hline & & & $\begin{array}{l}\text { Ev } \\
\text { sahibi } \\
\text { kadın }\end{array}$ & $\begin{array}{c}\text { Ev sahibi } \\
\text { kadın + } \\
\text { işçi }\end{array}$ & \\
\hline \multirow{2}{*}{ Merkez } & $\mathrm{n}$ & 8 & 77 & 2 & 87 \\
\hline & $\%$ & 9.2 & 88.5 & 2.3 & 100.0 \\
\hline \multirow{2}{*}{ Karakoyunlu } & $\mathrm{n}$ & 2 & 29 & 2 & 33 \\
\hline & $\%$ & 6.1 & 87.9 & 6.1 & 100.0 \\
\hline \multirow{2}{*}{ Aralık } & $\mathrm{n}$ & 3 & 36 & 2 & 41 \\
\hline & $\%$ & 7.3 & 87.8 & 4.9 & 100.0 \\
\hline \multirow{2}{*}{ Tuzluca } & $\mathrm{n}$ & 2 & 9 & 2 & 13 \\
\hline & $\%$ & 15.4 & 69.2 & 15.4 & 100.0 \\
\hline \multirow{2}{*}{ Genel } & $\mathrm{n}$ & 15 & 151 & 8 & 174 \\
\hline & $\%$ & 8.6 & 86.8 & 4.6 & 100.0 \\
\hline
\end{tabular}

Göçerlikle hayvancılık yapan işletmeler genellikle hayvanlar doğumlarını yaptıktan sonra kuzu ve oğlakları yaklaşık altı ay boyunca emzirmekteler ve daha sonra ise 2-3 ay gibi bir zamanda sütleri sağarak, peynir, tereyağ 1 ve lor gibi ürünlere işlemektedirler. Araştırmamızda Iğdır ilinde göçerlikle hayvancılık yapan işletmelerde koyunlarda günlük süt verimi ortalama $238.36 \pm 10.02 \mathrm{~g}$ gün$^{-1}$ olarak tahmin edilmiştir (Tablo 4). Koyunlarda günlük ortalama süt verimi ile ilgili elde edilen değer Bilginturan ve Ayhan (2009)'ın (448 g) ve Özalp ve Sayın (2018)'ın (290 g) bulgularından düşük olduğu görülmüştür.

Yarı göçer ailelerin sürülerinde kuzu emzirme süresi $147.18 \pm 1.55$ gün, koyun sağma süresi ise $59.02 \pm 2.00$ gün olarak belirlenmiştir (Tablo 4). İşletmelerde kuzu emzirme süreleriyle ilgili tespit edilen değer; Şahinli (2014)'nin (109.44 gün), Ceyhan ve ark. (2015)'nın (106.4 gün) ve Kayalık ve Bingöl (2015)'ün (76 gün) bulgularından yüksek iken, koyun sağma süresiyle ilgili belirlenen değerin Şahinli (2014)'nin (100.56 gün), Ceyhan ve ark. (2015)'nın (121.6 gün) ve Kayalık ve Bingöl (2015)'ün (76 gün) bulgularından düşük olduğu görülmüştür.

Göçer hayvancılıkla geçimini sağlayan işletmelerin damızlık koç ve anaç koyun ihtiyacını karşılamak için çoğunlukla kendi sürülerini ve meydanları tercih ettikleri belirlenmiştir (Tablo 5 ve 6).

Yetiştiriciler \% 81.6 oranında damızlık koç ihtiyacını karşılamada kendi sürülerini tercih ederlerken, \% 9.7'si hayvan pazarını ve \% 8.6's1 ise komşu ve komşu köylerinin sürülerini tercih ettiklerini ifade etmişlerdir (Tablo 5). Yetiştiricilerin damızlık koç ihtiyacını karşılamada kendi sürülerini tercih etmeleri ile ilgili elde edilen sonuç; Şahinli (2014)'nin Karaman'da (\% 52.0) ve Ceyhan ve ark. (2015)'nın Niğde'de (\% 68.8) koyunculuk işletmelerindeki bulgularından yüksek, Tamer ve Sarı̈zkan (2017)'nın Yozgat'ta (\% 88.8) belirlediği bulgudan düşük belirlenmiştir.

Tablo 6'daki bulgulara göre, işletmelerde \% 58.0 oranında anaç koyun ihtiyacı için kendi sürüleri tercih edilirken, \% 33.3 oranında komşu sürü ve köy sürülerinin, $\% 8.6$ oranında ise

Tablo 4. Sürü yönetiminde bazı uygulamalar ve verimler

\begin{tabular}{|c|c|c|c|c|c|c|c|}
\hline Uygulama & İlçeler & $\mathrm{N}$ & $\overline{\mathbf{x}}$ & $\mathbf{S}_{\overline{\mathbf{x}}}$ & Minimum & Maksimum & \\
\hline \multirow{5}{*}{$\begin{array}{l}\text { Koyun sağma } \\
\text { süresi } \\
\text { (gün) }\end{array}$} & Merkez & 87 & 55.57 & 3.07 & 0 & 120 & \multirow{4}{*}{$\begin{array}{l}\mathrm{F}=1.180 \\
\mathrm{p}>0.05^{\circ \ddot{s}}\end{array}$} \\
\hline & Karakoyunlu & 33 & 65.15 & 4.02 & 0 & 90 & \\
\hline & Aralık & 41 & 61.10 & 3.49 & 0 & 90 & \\
\hline & Tuzluca & 13 & 60.00 & 8.32 & 0 & 90 & \\
\hline & Genel & 174 & 59.02 & 2.00 & 0 & 120 & \multirow{5}{*}{$\begin{array}{l}\mathrm{F}=0.445 \\
\mathrm{p}>0.05^{\text {ös }}\end{array}$} \\
\hline \multirow{5}{*}{$\begin{array}{l}\text { Kuzu emme } \\
\text { süresi } \\
\text { (gün) }\end{array}$} & Merkez & 87 & 148.57 & 2.28 & 122 & 213 & \\
\hline & Karakoyunlu & 33 & 147.49 & 3.56 & 122 & 213 & \\
\hline & Aralık & 41 & 145.42 & 2.46 & 122 & 182 & \\
\hline & Tuzluca & 13 & 142.69 & 7.92 & 91 & 182 & \\
\hline & Genel & 174 & 147.18 & 1.55 & 91 & 213 & \multirow{6}{*}{$\begin{array}{l}\mathrm{F}=1.738 \\
\mathrm{p}>0.05^{\text {ös }}\end{array}$} \\
\hline \multirow{5}{*}{$\begin{array}{l}\text { Koyun günlük süt } \\
\text { verimi } \\
\left({\mathrm{g} g u ̈ n^{-1}}^{-1}\right.\end{array}$} & Merkez & 87 & 228.16 & 15.42 & 0 & 500 & \\
\hline & Karakoyunlu & 33 & 242.42 & 20.31 & 0 & 450 & \\
\hline & Aralık & 41 & 272.56 & 18.43 & 0 & 500 & \\
\hline & Tuzluca & 13 & 188.46 & 32.10 & 0 & 300 & \\
\hline & Genel & 174 & 238.36 & 10.02 & 0 & 500 & \\
\hline
\end{tabular}

ö.s: önemsiz 
Tablo 5. İşletmelerin koç ihtiyacını karşılama yöntemleri

\begin{tabular}{|c|c|c|c|c|c|}
\hline \multirow{2}{*}{ İlçeler } & & \multicolumn{3}{|c|}{ Damızlık koç ihtiyacını karşılama șekli } & \multirow{2}{*}{ Toplam } \\
\hline & & Kendi sürüsü & Hayvan pazarı & Komşu sürüler & \\
\hline \multirow{2}{*}{ Merkez } & $\mathrm{n}$ & 65 & 13 & 9 & 87 \\
\hline & $\%$ & 74.7 & 14.9 & 10.2 & 100.0 \\
\hline \multirow{2}{*}{ Karakoyunlu } & $\mathrm{n}$ & 30 & 2 & 1 & 33 \\
\hline & $\%$ & 90.9 & 6.0 & 3.0 & 100.0 \\
\hline \multirow{2}{*}{ Aralık } & $\mathrm{n}$ & 35 & 2 & 4 & 41 \\
\hline & $\%$ & 85.4 & 4.8 & 9.7 & 100.0 \\
\hline \multirow{2}{*}{ Tuzluca } & $\mathrm{n}$ & 12 & 0 & 1 & 13 \\
\hline & $\%$ & 92.3 & 0.0 & 7.7 & 100.0 \\
\hline \multirow{2}{*}{ Genel } & $\mathrm{n}$ & 142 & 17 & 15 & 174 \\
\hline & $\%$ & 81.6 & 9.7 & 8.6 & 100.0 \\
\hline
\end{tabular}

Tablo 6. İşletmelerin Damızlık koyun ihtiyaçlarını karşılama yolları

\begin{tabular}{|c|c|c|c|c|c|}
\hline \multirow{2}{*}{ İlçeler } & & \multicolumn{3}{|c|}{ Damızlık koyun ihtiyacı karşılama } & \multirow{2}{*}{ Toplam } \\
\hline & & Kendi sürüsü & Hayvan pazar1 & Komşu sürüler & \\
\hline \multirow{2}{*}{ Merkez } & $\mathrm{n}$ & 51 & 13 & 23 & 87 \\
\hline & $\%$ & 58.6 & 14.9 & 26.4 & 100.0 \\
\hline \multirow[b]{2}{*}{ Karakoyunlu } & $\mathrm{n}$ & 22 & 1 & 10 & 33 \\
\hline & $\%$ & 66.7 & 3.0 & 30.3 & 100.0 \\
\hline \multirow{2}{*}{ Aralık } & $\mathrm{n}$ & 22 & 1 & 18 & 41 \\
\hline & $\%$ & 53.7 & 2.4 & 43.9 & 100.0 \\
\hline \multirow{2}{*}{ Tuzluca } & $\mathrm{n}$ & 6 & 0 & 7 & 13 \\
\hline & $\%$ & 46.2 & 0.0 & 53.8 & 100.0 \\
\hline \multirow{2}{*}{ Genel } & $\mathrm{n}$ & 101 & 15 & 58 & 174 \\
\hline & $\%$ & 58.0 & 8.6 & 33.3 & 100.0 \\
\hline
\end{tabular}

meydanların tercih edildiği tespit edilmiştir. Yetiştiricilerin damızlık koyun ihtiyacını karşılamada kendi sürülerini tercih etme ile ilgili elde edilen değer Bilginturan ve Ayhan (2009)'ın (\% 91.2) ve Tamer ve Sarıözkan (2017)'ın (\% 88.8) elde ettikleri değerlerden düşük iken, Şahinli (2014)'nin (\% 51.0) bildirdiği değerle uyum içinde olduğu görülmüştür.
Yetiştiricilerin mera ve yaylaların dışında hayvan besleme alışkanlıkları ile ilgili bilgiler Tablo 7'de verilmiştir. Buna göre, koyunlara günde ortalama $2.91 \pm 0.03 \mathrm{kez}$ yem verildiği, anaç koyun başına ortalama kesif yem miktarının $566.38 \pm 15.68 \mathrm{~g}$ olduğu, misir silaji verenlerin günlük ortalama anaç koyun başına $(n=8)$ $700.00 \pm 118.02 \mathrm{~g}$ silaj verdiği, verilen saman

Tablo 7. Koyunlarda günlük yemleme sıklığı ve verilen yem miktarları

\begin{tabular}{|c|c|c|c|c|c|c|}
\hline Bazı yem-besleme uygulamaları & $\mathrm{N}$ & $\overline{\mathbf{X}}$ & $\mathbf{S}_{\overline{\mathbf{x}}}$ & Medyan & Minimum & Maksimum \\
\hline Koyun yemleme sayısı (adet) & 174 & 2.91 & 0.03 & 3 & 2 & 4 \\
\hline Koyun kesif yem (g gün $\left.{ }^{-1}\right)$ & 174 & 566.38 & 15.68 & 500 & 50 & 1.000 \\
\hline Misır silaj1 (g gün-1) & 8 & 700.00 & 118.02 & 750 & 200 & 1.000 \\
\hline Saman (g gün-1) & 96 & 900.00 & 55.09 & 1000 & 100 & 3.000 \\
\hline Çayır+kuru ot $\left(\mathrm{g}\right.$ gün $\left.{ }^{-1}\right)$ & 164 & 1449.70 & 43.89 & 1500 & 500 & 3.000 \\
\hline İlk kolostrum alma (dakika doğum ${ }^{-1}$ ) & 174 & 19.74 & 1.23 & 10 & 5 & 60 \\
\hline
\end{tabular}

miktarının $900.00 \pm 55.09$ g olduğu ve günlük verilen kuru ot miktarının ise ortalama $1449.70 \pm 43.89$ g olduğu görülmektedir. Kuzu ve oğlakların doğum sonrası kolostrumu ilk alma süresinin ortalama $19.74 \pm 1.23$ dakika içinde olduğu belirlenmiştir (Tablo 7). Kuzuların doğum sonrası kolostrumu ilk alma süresi ile ilgili elde edilen değer Ürüşan ve Emsen (2010)'in (30 dakika) elde ettikleri değerden düşük elde edilmiştir.
Yetiştiricilerin hayvanlarından elde ettikleri sütleri nasıl değerlendirdikleri ilçeler bazında incelenmiş olup, Tablo 8'de verilmiştir. Çig süt değerlendirmede yetiştiricilerin $\% \quad 80.5$ 'i sütü satmakta, \% 10.9'u öz tüketimde kullanmakta ve $\%$ 8.6'sı ise sağım yapmamaktadır (Tablo 8). İşletmelerde yetiştiricilerin elde ettikleri sütleri çiğ süt olarak satmaları ile ilgili elde edilen değer; Bilginturan ve Ayhan (2009)'ın (\% 7.2), Tamer ve Sarıözkan (2017) (\% 50.4) ve Özalp ve Sayın 
(2018)'ın (\% 14.0) bildirdiği değerden yüksek belirlenmiştir. Bununla birlikte Ceyhan ve ark. (2015)'nın Niğde ilinde ve Karadaş (2018)'ın Hakkari ilindeki çalışma bulgularına göre koyunculuk işletmelerinde çiğ süt satış1 yapılmamakta, elde edilen sütler ürünlere işlenerek aile ihtiyacının karşılanmasında ve ihtiyaç fazlası mamüller satışa sunulmaktadır.

Tablo 8. İşletmelerde süt değerlendirme şekli

\begin{tabular}{lccccr}
\hline \multirow{2}{*}{ İlçeler } & \multicolumn{4}{c}{ Süt değerlendirme şekli } & \\
\cline { 2 - 5 } & \multicolumn{3}{c}{$\begin{array}{c}\text { Sağım } \\
\text { yok }\end{array}$} & $\begin{array}{c}\text { Öz } \\
\text { tüketim }\end{array}$ & $\begin{array}{c}\text { Süt } \\
\text { satış1 }\end{array}$ \\
\hline \multirow{2}{*}{ Merkez } & $\mathrm{n}$ & 8 & 16 & 63 & 87 \\
& $\%$ & 9.2 & 18.4 & 72.4 & 100.0 \\
\hline \multirow{2}{*}{ Karakoyunlu } & $\mathrm{n}$ & 2 & 2 & 29 & 33 \\
& $\%$ & 6.1 & 6.1 & 87.9 & 100.0 \\
\hline \multirow{2}{*}{ Aralık } & $\mathrm{n}$ & 3 & 1 & 37 & 41 \\
& $\%$ & 7.3 & 2.4 & 90.3 & 100.0 \\
\multirow{2}{*}{ Tuzluca } & $\mathrm{n}$ & 2 & 0 & 11 & 13 \\
& $\%$ & 15.4 & 0.0 & 84.6 & 100.0 \\
\hline \multirow{2}{*}{ Genel } & $\mathrm{n}$ & 15 & 19 & 140 & 174 \\
& $\%$ & 8.6 & 10.9 & 80.5 & 100.0 \\
\hline
\end{tabular}

Yetiştiricilerin göçerlikle elde ettikleri hayvansal ürünleri gerek çiğ süt olarak gerekse mamule işleyerek pazarladıkları fiyatlar Tablo 9'da verilmiştir. Yetiştiricilerin elde ettikleri süt ve süt ürünlerinin satış fiyatları; peynirde ortalama $6.25 \pm 1.84 \mathrm{TL} \mathrm{kg}{ }^{-1}$, çiğ sütte $1.95 \pm 0.21 \mathrm{TL} \mathrm{kg} \mathrm{kg}^{-1}$, yoğurtta $3.00 \pm 0.0 \mathrm{TL} \mathrm{kg} \mathrm{kg}^{-1}$, terayağında $18.83 \pm 5.85$ TL $\mathrm{kg}^{-1}$ ve lorda $4.25 \pm 1.50 \mathrm{TL} \mathrm{kg} \mathrm{kg}^{-1}$ şeklindedir (Tablo 9). Koyunlardan elde edilen çiğ süt satış fiyatı ile ilgili değer; Özalp ve Sayın (2018)'ın (4.74 TL $\mathrm{kg}^{-1}$ ) bildirdiği değerden düşük elde edilmiştir.

Tablo 9. İşletmelerde süt ve mamul satış fiyatları

\begin{tabular}{lccccc}
\hline $\begin{array}{l}\text { Mamul } \\
\text { fiyatları }\end{array}$ & $\mathrm{N}$ & $\overline{\mathbf{X}}$ & $\mathbf{S}_{\overline{\mathbf{x}}}$ & Minimum & Maksimum \\
\hline Peynir & 84 & 6.25 & 1.84 & 3 & 13 \\
Süt & 66 & 1.95 & 0.21 & 1 & 2 \\
Yoğurt & 2 & 3.00 & 0.00 & 3 & 3 \\
Tereyağ1 & 6 & 18.83 & 5.85 & 10 & 25 \\
Lor & 4 & 4.25 & 1.50 & 3 & 6 \\
\hline
\end{tabular}

\section{Sonuçlar}

İşletmelerde küçükbaş hayvan yetiştiriciliğinin sürdürülebilirliğini sağlamak için kaba yem üretiminin de devamlılığının sağlanması gerekir. İşletmelerde yeteri kadar kaba yem üretilmesi; mera ve yayla alanlarının tahrip edilmesine sebep olan erken ve aşırı otlatma gibi problemleri de azaltacaktır. Iğdır ili yarı göçer ailelerin hayvanları için mera ve yayla dönemi dışında protein ve enerji ihtiyaçlarının karşılanmasında yonca ve silajlık mısır üretmeleri teşvik edilerek, yemin hem kaliteli hem de ucuz olması sağlanmalıdır. Yüksek oranda bir hayvancılık organizasyonuna kayıtlı olan bu yetiştiriciler için yetkililer ve bağlı bulundukları hayvancılık organizasyonları tarafindan, mera yönetimi, yem bitkisi üretimi, hayvan bakımbesleme, damızlık hayvan seçimi, sürülerde sağlık koruma ve aşılama gibi sürü yönetimi konusunda her yıl tekrarlanan bir program dâhilinde bilinçlendirici eğitim verilmesi önerilir. Böylece, mera ve yayla alanlarının kullanımı konusunda göçerlikle yapılan hayvancığın geliştirilmesine, milli kaynakların yerinde kullanılmasına ve ekonomiye kazandırılmasında olanak sağlayacaktır.

\section{Kaynaklar}

Aygün, T., Sezgin, Y., 2009. Ülkemizde göçer küçükbaş hayvanc1lık faaliyetleri: Bitlis ili örneği. 6. Ulusal Zootekni Bilim Kongresi, Bildiriler Kitab1, 24-26 Haziran, Erzurum, s. 398-406.

Bilginturan, S., Ayhan, V., 2009. Burdur ili Damılık Koyun ve Keçi Yetiştiriciler Birliği üyesi koyunculuk işletmelerinin yapısal özellikleri ve sorunları üzerine bir araştırma. Hayvansal Üretim, 50(1): 1-8.

Ceyhan, A., Şekeroğlu, A., Ünalan, A., Çınar M., Serbester U., Akyol E., Yılmaz, E., 2015. Niğde ili koyunculuk işletmelerinin yapısal özellikleri ve sorunlar1 üzerine bir araștırma. Kahramanmaras Sütçü İmam Üniversitesi Doğa Bilim Dergisi, 18(2): 46-58.

Dașc1, M., Comaklı., B., 2006. Yaylacılık ve tarımsal açıdan önemi. Atatürk Üniversitesi Ziraat Fakültesi Dergisi, 37(2): 275-280.

Herzog, F., Seidl, I., 2018. Swiss Alpine summer farming, current status and future development under climate change. The Rangeland Journal, 40: 501-511.

Kayalık, M.Ş., Bingöl, M., 2015. Tüm yönleriyle morkaraman koyunları. Iğdır Üniversitesi Fen Bilimleri Enstitüsü Dergisi, 5(2): 89-97.

Karadaş, K., 2017. Sanlıurfa ilinde koyunculuk işletmelerinin sosyo-ekonomik durumu: Siverek ilçesi örneği. Gümüşhane Üniversitesi Fen Bilimleri Enstitüsü Dergisi, 7(2): 268-279.

Karadaş, K., 2018. Koyunculuk işletmelerinin sosyoekonomik durumu Hakkâri ili örneği. Atatürk Üniversitesi Ziraat Fakültesi Dergisi, 4(1): 29-35.

Kaymakçı, M., 2016. İleri Koyun Yetiştiriciliği Kitabı. (Genişletilmiş 5. Bask1), İzmir.

Kuşvuran, A., Nazlı, R.İ., Tansı, V., 2011. Türkiye'de ve Batı Karadeniz Bölgesi'nde çayır-mera alanları, hayvan varlığ1 ve yem bitkileri tarımının bugünkü durumu. Gazi Osmanpaşa Üniversitesi Ziraat Fakültesi Dergisi, 28(2): 21-32.

Küçükilhan, A., Palabıyık, Ö., Yılmaz, O., 2011. Denizli ili Serinhisar ilçesi göçer koyunculuk faaliyetleri. VII. Ulusal Zootekni Öğrenci Kongresi, 20-22 Mayıs, Aydın, s. 276. 
Özalp, M., Sayın, C., 2018. Antalya'da küçükbaş hayvancılıkta sürdürülebilirliğe etki eden ekonomik faktörlerin değerlendirilmesi. Kahramanmaraş Sütçü İmam Üniversitesi Tarım ve Doğa Dergisi, 21(1): 111.

Savaș, İ., Yılmaz, İ., Yanar, M., 2019. Iğdır ilinde göçer hayvancıl1k ve bazı yapısal özellikleri. I $\breve{g} d \imath r$ Üniversitesi Fen Bilimleri Enstitüsü Dergisi, 9(1): 552-561.

Şahinli, M., 2014. Koyunculuk sürü yönetimi: Karaman ili örneği. Anadolu Tarım Bilimleri Dergisi, 29(2): 113-120.

Tamer, B., Sarı̈özan, S., 2017. Yozgat merkez ilçede koyunculuk yapan işletmelerin sosyo-ekonomik yap1s1 ve üretim maliyetleri. Erciyes Üniversitesi Veteriner Fakültesi Dergisi, 14(1): 39-47.

Uzun, A., Köse, A., 2012. Madra Dağı'nda geleneksel yayla göçü. Sosyal Bilimler Enstitüsü Dergisi, 15(28-1): 9-17.

Ürüşan, H., Emsen, H., 2010. Kuzulama mevsimi, kuzu genotipi, anne ve doğumla ilgili faktörlerin kuzuların büyüme ve yaşama gücü üzerine etkileri. Tekirdağ Ziraat Fakültesi Dergisi, 7(3): 163-172.

Yamane, T., 2010. Temel Örnekleme Yöntemleri. Literatür Yayınc1lık, İstanbul.

Yazıc1, M., 2016. Modern göçerlik. Elektronik Sosyal Bilimler Dergisi, 15(56): 235-252.

Yıldız, N., Akbulut, Ö., Bircan H., 2006. İstatistiğe Giriş, Uygulamalı Temel Bilgiler, Çözümlü ve Cevaplı Sorular. Aktif Yayınevi, İstanbul.

Yolcu, H., Tan, M., 2008. Ülkemiz yem bitkileri tarımına genel bir bakış. Tarım Bilimleri Dergisi, 14(3): 303-312. 